\title{
Legacy of Colonialism \\ in the Empowerment of Women in Rwanda
}

\author{
Ilaria Buscaglia \\ University of Siena \\ Shirley Randell \\ Kigali Institute of Education, Rwanda
}

\begin{abstract}
This paper aims to trace the genealogy of discourses and practices relating to the empowerment of women in Rwanda. Their origins are rooted in colonial times, particularly in some social welfare programs for women, known as foyers sociaux (social homes), in which Rwandan women were taught to cook, iron, mend and clean, in a word how to be good wives. The foyer social constitutes a revealing example of the ambiguity brought by the colonial idea of "female promotion": conceived as a way to improve women's condition, they actually contribute to their domestication, by inculcating Victorian gender ideology in the African élite and erasing traditional forms of female pre-colonial power at the same time. This program was reproduced in different forms in postcolonial Rwanda, as the case of the Karubanda Social School clearly shows. In the end, the paper briefly considers, what caused the situation to change following the genocide against the Tutsi in 1994, and what more might be done to stimulate full gender equality in education and employment for women in Rwanda.
\end{abstract}

\section{Introduction}

The notion of "female promotion" was introduced in Congo and Ruanda-Urundi by the Belgian colonizers to indicate the social and political measures intended to enhance women's position in the society and to encourage what was supposed to be a "more developed" conception of femininity. ${ }^{1}$ In this paper, “female promotion” will be considered as a Foucauldian apparatus, i.e.

[...] a thoroughly heterogeneous set consisting of discourses, institutions, architectural forms, regulatory decisions, laws, administrative measures, scientific statements, philosophical, moral, and philanthropic propositions-in short, the said as much as the unsaid. Such are the elements of the apparatus. The apparatus itself is the network that can be established between these elements [...] (Foucault, cit. in Agamben 2009, p. 2).

\footnotetext{
${ }^{1}$ In the Belgian colonial context, the expression "female promotion" (itself a translation of the French promotion féminine) appeared for the first time in the proceedings of a conference held in Brussels in 1956, focusing on the promotion of native women from Congo and Ruanda-Urundi. The phrase is in itself problematic for two reasons. First, it assumes that there exists one "good" model of femininity towards which all the alternatives should be directed. Secondly, it implies a certain passivity on the part of women themselves as if they weren't capable of defining their own aims and lives. For these reasons the expression "women's empowerment" which focuses more on the active role of the subjects was later substituted. Throughout the paper we explicitly use "female promotion" in a pointed reference to the colonial mind-set of the time.
} 
The analysis will focus especially on the origins of this apparatus, rooted in colonial times, and on its progeny, by showing the way it affected even postcolonial gender ideology up to 1994. The aim of the study is twofold: on one hand, it tries historically to reconstruct the basis of gender inequality, by clearly showing how misleading it is to blame a conjectural local tradition or culture, without taking into account the colonial encounter. Secondly, it suggests that people in charge of planning political and social measures to enhance women's (or any groups') condition should always critically re-analyze and rethink previous models of empowerment before automatically applying them.

\section{The Foyers Sociaux and Female Promotion in Colonial Times}

The dawn of female promotion in Rwanda dates back to the 1940s, when Rwanda, together with Burundi, formed the territory of Ruanda-Urundi. This was administered by Belgium under mandate first, and as a United Nations (UN) Trust Territory after 1945. Every year, Belgium had to send a complete report to the UN, in which all details about the condition of the colony had to be given. Reports had roughly the same structure every year: they listed answers to approximately 250 questions, organized in chapters on geography, economy, social affairs, education, hygiene and public health.

Women began to be the object of some attention in these documents from the beginning of the 1950s, especially in the chapters on social assistance. ${ }^{2}$ In the seventh chapter of the 1951 report, entitled 'Social Progress', it is written: ‘[W]hat we call social assistance must not be seen in a general sense, but in the strict meaning of domestic and familiar education of the indigenous woman’ (Ministre des Colonies 1952, p. 112). Women are presented as the beneficiaries of an educational welfare program sponsored by the colonial government and known as foyers sociaux (social homes).

The first foyer was founded in Usumbura in 1948; two others followed in Astrida (1949) and Nyundo (1952). The foyer in Usumbura institutionalized a previous informal activity carried out by the White Sisters. In 1946, together with some lay women, they began to teach dressmaking to some African women from a part of the town called Belge, the quarter where

\footnotetext{
${ }^{2}$ Some references could also be found in the chapters on education, where the few girls' schools and their activities were mentioned, and in the chapters on public health, where women appeared exclusively as mothers who benefit from the sanitary maternal and child programs. But only in the chapters on social progress are there any considerations about the concept of female promotion and women's emancipation.
} 
évolués lived, i.e. indigenous men educated in colonial schools and resident in urban centres who constituted the native élite. In 1948 a professional association of the Catholic social service, the Assistance Sociale au Congo, took over, and the sisters were substituted by social assistants. This became an 'agreed' institution, managed by a private organization. It had nonetheless to follow the guidelines of the colonial government, which also provided funds. ${ }^{3}$

According to the 1951 report, courses offered in the foyers of Astrida and Usumbura were the following: mass courses, i.e. general courses of dressmaking and knitting for all the women enrolled,

[n]ot to teach them to make embroidered dresses, artistically made, but simple clothes easy to finish and thanks to which the members of the family will always be clean and well-groomed (Ministre des Colonies 1952, cited in Hunt 1990, p. 456).

Then the permanence, i.e. the possibility for each woman to be individually followed up in her sewing work twice a week. After six months or one year, the best students were chosen to start domestic courses, aiming at shaping

[r]eal ladies of the house, able to keep the house clean, to make the interior pleasant and to offer a cleaned table, an appetizing meal and washed linen to their husbands when they come from work (Ministre des Colonies 1952, p. 113).

Once a week the women washed, ironed and mended the linen; another time they cooked a complete meal that was then eaten at home with their families. To check that the notions learnt at the foyers were effectively put into practice and transmitted to neighbors, home visits were made by the directors of the foyers. The latter were also expected to intervene in case of conflicts between the students and their families. Eventually, women could also benefit from saving books in order to buy a sewing machine or a cradle. Some women (nine in Usumbura according to the 1951 report) were chosen to be trained as indigenous instructors in order to help the Europeans in their work.

The role of the foyers sociaux was at the centre of the discourses pronounced in the 12th session of the National Colonial Congress, held in Brussels in 1956, focusing on the promotion of the indigenous woman. Their multiplication, together with an extension of their activities, was seen as a good strategy to improve the life conditions of women and girls.

\footnotetext{
${ }^{3}$ The history and analysis of the foyer in Usumbura are drawn from Hunt (1990, pp. 455-456).
} 
They should reach the same level as their male counterparts, the évolués. The ideal couple was formed by an évolué husband, holder of a civic merit card, and a wife, diligent student at the foyer social. The Minister of the Colonies said:

[i]f we have already noticed a remarkable progress on the part of African society which includes only the male element, it is not the same with the female population. The fault is not only ours. At the beginning, the pioneers were more interested in securing a labor force in order to draw a better organization from an ethnic status stuck from time immemorial in the ancestral rut of routine and custom (Congrès Colonial National 1956, pp. 18-19).

And also:

[I]f we have been able to gain an élite out of the male population, which has been growing on and on, it has not been the same for the female population. And it is this delay, due to the will to not suddenly disrupt the basis of an ancestral structure, this rational respite in our civilizing mission, which enhances your task with a peculiar and frightening interest (Congrès Colonial National 1956, p. 19).

Raising women to the same level of emancipation as the évolué men was therefore seen as a gradual process, to be accomplished cautiously to avoid the sudden eradication of structures and gender relationships which had been consolidated by an ancient tradition. Women were also seen as the bearers of traditional culture. The President of the Congress stated: '[e]ven more than men, women are trapped in the culture’ (Congrès Colonial National 1956, p. 25). Women were also those responsible for the first education of their children:

[T]hey deeply love their children. When the latter reach the age of school, they are already imbued with their mother's concepts. Let us raise the indigenous woman for her interest, for the happiness of an harmonious family and also for a better future. To educate a boy is to form a man; to educate a girl is to form a family (Congrès Colonial National 1956, p. 25).

Women had to be led to free themselves from a traditional culture which was seen as a hindrance to their personal and collective development. In doing so, they would easily become good spouses and responsible mothers, with positive social and moral effects on the new generations (their children), the men (their husbands), their families and, in consequence, the whole society. 
It was considered that the emancipation process should involve first the women resident in the centers extra-coutumiers ${ }^{4}$ because their life condition was perceived as constantly at risk. Without the control of traditional culture and in the absence of an alternative moral order, these women could easily misuse their freedom. In the opinion of the Vice-governor of Congo:

[w]hile in the traditional villages, women suffer as a beast of burden and men are usually quite idle, in the centers extra-coutumiers men work and their wives become aware of their freedom and often they use it improperly (Congrès Colonial National 1956, p. 36).

Female promotion became a strategy of control of the potential disorder due to the moral crisis caused by urban migration. Gender power relations had been completely reversed: in rural areas women worked hard in the field and had no time for leisure, while in town they stayed at home without the control of their husbands, who worked the whole day for the colonial administration. Unready to perform the role of unproductive wives, it was considered that these women could be tempted by prostitution, adultery and alcoholism, with a consequent increase in divorces.

Female promotion went hand in hand with social control. The combined action of missionaries, social assistants and colonial authorities was meant to hold back this potential explosive disorder and to organize it according to precise gender roles: men were at the service of the colonial power and they maintained their families through their work; women were confined to the reproductive sphere, with the task of perpetuating the labor force and bringing up their children. Men as producers and women as re-producers: this dichotomy, which had been proposed and analyzed by Meillassoux (1975), seems to be rooted in colonial times and would not be seen as traditional at all, in a society where women were important agricultural workers.

Female promotion finally coincided with the imposition of a precise family structure of European origin, the nuclear family, with the related gender roles. The Minister of the Colonies stated: ' $[\mathrm{t}]$ he promotion of the black woman is necessary if we want to put at the basis of the Congolese community the harmony of the évolué couple’ (Congrès Colonial National 1956, p. 20).

\footnotetext{
${ }^{4}$ Colonial towns, under the rule of colonial law.
} 
Even the laws operating on the colonial territory showed the same intention. The 1957 report states that two decrees issued by the colonial administration were meant to facilitate women's life conditions: the decree of 5 July 1948, that required the inscription of traditional marriage in the register of births, marriages and deaths, and the decree of 4 April 1950, that annulled all marriages contracted from 1952 onwards by already married men (Ministre des Colonies 1958, p. 129). These dispositions ratified a formal acknowledgment of the monogamous union, together with an official sanction against polygamy. No polygamous family could take up residence in town. Finally, the institution of a supplementary tax on polygamy in the 1930s must be mentioned: every man had to pay a levy on every wife but the first. The monogamous model had to be consolidated first in the native élite, resident in urban areas, and then transmitted to the rest of the population, in order to avoid: '[t]he creation of a caste of more or less europeanized black men and women, segregated from the mass of autochthonous people’ (Congrès Colonial National 1956, p. 94). Actually, the class division of the colonized was one of the principal strategies of colonial control, as Hunt brilliantly points out:

[T] he foyer social thus became a key part of colonial efforts to solidify the class structure of Usumbura's African residents and inscribe within this class structure colonial standards of prestige and status. In so doing, the foyer worked to establish, maintain, and enhance hierarchies among women, among Africans, between men and women, and between white colonials and Africans (1990, p. 474).

The crafting of these new subjectivities was carried out through direct contact between the European instructors and African women, occurring in the kitchen, in the sewing class or in the laundry. In this domestic atmosphere, a space of 'colonial intimacy' was created, in which the relationship of domination between colonizers and colonized had not the aspect of a patent coercion, but of what Homi Bhaba calls 'colonial mimicry' (Hunt 1990, p. 469). The students in the foyers sociaux were called to imitate the behaviors of European women in everyday activities, like cooking, washing the linen, ironing and welcoming their husbands back from work. This fine embodiment of gestures only looks innocent: it is actually one of the most effective and pervasive ways of shaping subjects and creating an indigenous élite. And African individuals had an active part in it: they were not only passive recipients. A young Congolese student in Belgium noticed: '[t]hose gestures that are spontaneous for you, we can only make them after reasoning' (Congrès Colonial National 1956, p. 49). 
Though the simple transplant of western models was seen as inopportune by most of the intellectuals of the time, the practical realization of social assistance programs actually showed a different tendency. One of the évolués present at the Congress noticed: '[I] saw that in one of the foyers sociaux, the women were taught to cook on an electric cooker or on a petrol one, and to use electric irons’ (Congrès Colonial National 1956, p. 133). He added: '[I]n other foyers sociaux, our wives are taught to prepare onion soup or European specialties. I think it is a waste of time for the wife of a worker' (Congrès Colonial National 1956, p. 133).

In this mimicry, as Hunt stresses in her article, there was no place for a fusion: each part was confirmed in its own position, through a delicate counterbalance of approach and recession between the colonizers and the colonized. The aim was to create a local élite, separated from the mass, which did not call into question the racist hierarchies on which the colonial experience was based:

[F]or élite Africans, measures designed to seduce their participation and cooperation were as salient as forms of distancing from the colony. Although targeted for special attention and inducements by the foyers, their distinct place in the racist colonial hierarchy was ultimately reinforced, even as their elite position among Africans was simultaneously delineated (Hunt 1990, pp. 449-50).

The foyers sociaux thus became an instrument to create a selected and urban model of femininity: the woman must be a wife and a mother, and her work must be limited to the domestic sphere. According to one of the participants at the Congress, the aim of female promotion was: '[T] o raise women to their traditional role reserved to them in the Christian family, central in our culture and whose importance goes even beyond our laws' (Congrès Colonial National 1956, p. 51).

But are we sure that this new model of femininity is a real way of promoting women? Did colonization really emancipate African women as it was stated by the authorities of the time? Was the new female élite of wives and mothers more powerful than the one in pre-colonial times? 


\section{A Pre-colonial Élite of Powerful Women}

During colonial times, several wives of chiefs, queen mothers and princesses had important roles in Rwandan history, not to mention that the structure of power itself was based on the couple, king-and-queen mother, as in other African kingdoms of the region (and far away) (De Heusch 1958 and 1972; Cohen 1977; Schiller 1990). In some historiographical works (Muzungu 2003; Vansina 2004; Prunier 1995), examples can be found. The best-known is the figure of Kanjogera Nyirayuhi, who did not hesitate to sentence to death Rutarindwa, her adoptive child, heir to the throne, in order that her own son could seize power. This occurred in 1896 and is known as 'the coup d'Etat de Rucuncu'. The reign of Yuhi Musinga followed, where the power was de facto in the hands of his mother and her brothers. In addition to the example of Kanjogera, notorious for political intrigues, it is worth mentioning the case of Nyiratunga, adoptive queen mother of Yuhi IV Gahindiro at the end of the 19th century. Nyiratunga reigned wisely until her son reached full age and then she ceased power without arousing hostility. Another important figure is Nyirarumaga, adoptive queen mother of Ruganzu Ndori (16th century). Nyirarumaga is reputed to have reformed the style of ibisigo, the historical poems that listed names and deeds of the past kings, from their origin up to the time of their composition. ${ }^{5}$

As Schiller points out with regard to the Kingdom of Buganda: ‘[p]olitical status transcended gender status’ (1990, p. 457). Queen mothers, kings’ sisters, princesses and several kings’ wives, whose status derived from the position of their respective sons, brothers, fathers or husbands, could nonetheless exercise a direct political power on the men of their own courts and an indirect one on the kings and their courts. They could do it to favor the members of their lineage or just to influence more general political decisions. Women’s political power, although confined in the royal court, was not absent from society.

These queens and princesses seem very distant from the wives of colonial évolués, whose promotion coincided with their domestication. We can therefore conclude that the dismantling of the monarchy with its rites, roles, symbols, among which was the figure of the queen mother, led to women's retirement from political power. The idea is very close to Amadiume’s remarks about the Igbo of Nigeria:

\footnotetext{
${ }^{5}$ We are grateful to Dr Jeanne Nyirahabimana, Professor at the National University of Rwanda for the precolonial female portraits. She is currently recording an important historiographical work on the role of women during pre-colonial and colonial times in Rwanda.
} 
[w]hereas indigenous concepts linked to flexible gender constructions in terms of access to power and authority mediated dual sex divisions, the new western concepts introduced through colonial conquest carried strong sex and class inequalities supported by rigid gender ideology and constructions: a woman was always female regardless of her social achievements or status (1987, p. 119).

Colonization is seen by the author as 'the erosion of women's power'.

\section{Post-colonial Times and the Progeny of the Karubanda Social School}

The concept of female promotion elaborated in colonial times was at the basis of all the following educational and social programs for women disposed by the independent Rwandan State. It has to be added that the dismantling of the female pre-colonial élite together with the monarchical structure itself, depended also on ethnic dynamics. Before the Second World War, the colonial strategy of dominance implied the support of the minority on power (Nyiginya dynasty, a small fragment of a Tutsi lineage). After 1945, the paradigm changed in favor of the mass of the population, globally identified with the Hutu majority. The struggle for independence was led from an anti-monarchic perspective: all the previous political and social models were abhorrently identified with the Tutsi ethnic group and they had to be removed (Fusaschi 2000). For this reason, even the role of queens and princesses came to an end, substituted by a female évoluée élite, forged in the foyers sociaux according to a pure western model.

The Karubanda Social School, which started its activities on 1 October 1956, is a good example of the penetration of the colonial concept of female promotion in the post-colonial State. The School was founded by the Soeurs Auxiliatrices des Ames du Purgatoire, with the approval and the economic support of the Ministry of the Colonies. The Soeurs provisionally started the school in Gisagara and they settled permanently in Astrida (Butare) three years later, in $1959 .^{6}$

The main objectives of the school were the following:

\footnotetext{
${ }^{6}$ This information, when not specified, is drawn from Ngendakumana (1989). Ngendakumana was a professor at Karubanda school who conducted personal research about the history of the school.
} 
- To offer education 'whose aim is to train rural indigenous social assistants, in a spirit of tolerance and respect, and beyond any form of proselytism, ${ }^{7}$

- To 'train young autochthonous girls so that they will be in a position to manage little rural social centers that will multiply in the two countries under the auspices of the Government and the Chiefdom Council' 8

- $\quad$ To take care of the rural mass not yet involved in Western education.

The explicit aim was to train social indigenous assistants who could work specifically in the foyers sociaux. ${ }^{9}$ The implicit aim, mentioned by Ngendakumana in his work, was to shape potential wives for the évolués, educated in the Groupe Scolaire and known as Indatwa:

[t]he Groupe Scolaire of Butare, created in 1929, trained agents for the colonial administration who could not easily find companions able to satisfy them on many aspects of relational or socio-professional life. Their dressing habits, their way of eating, speaking, their religious beliefs, their sanitary habits, their conception of the world, of the environment and of the culture, have changed to the extent that we must train women as their life companions, who could complete them from a professional, personal, familiar and social point of view (Ngendakumana 1989, pp. 47-48).

Girls who had completed five years of primary school with a final mark of at least 8/10 were admitted. The recruitment was executed through applications coming from religious congregations or parishes, or from native families.

The educational program encompassed four years. The first year was equivalent to the sixth year of primary school and a general background was given: French, history, sciences and geography were taught. Three years of theoretical and professional social studies followed: psychology, law, social organization, anatomy, pediatric nursing, maternal and child hygiene were the main subjects. The practical part included home economics courses and internships at the foyers sociaux. Textbooks used were written by the teachers themselves who drew information from leaflets of Nestlé or Guizot and from books written by missionaries in Congo. Karubanda Social School soon became a model. Several religious and lay people

\footnotetext{
${ }^{7}$ Art. 8 of the provisional convention drawn from Ngendakumana (1989), p. 42.

${ }^{8}$ Excerpt from the activity report of the year 1957-1958, ibid.

${ }^{9}$ There is a strong link between the two realities: the staff of the school was under the control of Aimo (Affaires Indigènes et Main d'Oeuvres) and had to do internships at the foyers of Astrida and Nyundo before starting teaching.
} 
wrote to the director, Sister Marie de St. Etienne, to ask her advice on how they could start a similar activity in different areas of the Belgian colonies (Ngendakumana 1989, p. 35).

The colonial model of female promotion through social assistance was consolidated during the two Republics, adapting itself according to governmental trends. Social action, between the 1970s and 1980s not only focused on women, but became a development action which aimed at involving the rural and popular mass as a whole. For this reason not only did female social schools increase (in Byumba a new one was opened in 1979, in Rambura and in Rulindo in 1981), but also one for boys was founded in Kansi in the 1970s. Alongside the foyers sociaux the CCDFP (Centres Communaux de Développement et Formation Permanente) were created. In these new institutions boys and men were also included. Women remained, nevertheless, the main beneficiaries of social assistance.

The few women in politics during Habyarimana's regime had all studied at Karubanda Social School: among them the notorious Pauline Nyiramasuhuko, ${ }^{10}$ Minister of Equal Opportunities from 1992, Agathe Kanziga, Habyarimana’s wife and Immaculée Nyirabizeymana, a deputy and a politician. Agathe Uwilingiyimana, member of the opposition and Prime Minister of the Government that issued from the Arusha agreement, worked there as a Mathematics teacher (Guichaoua 1995). All examples of emancipated women of the time, they had a background as social assistants. Until very recently, this had been the only path for women towards 'emancipation'.

\section{Changing Emphases}

Things started to change at the end of the 1980s, when some women in civil society began to organize themselves following the international trend of female activism inaugurated by the 1985 UN International Conference in Nairobi at the end of the Decade for Women. Several women's associations were created, such as Duterimbere, Haguruka, Reseau des Femmes and Pro-femmes Twese Hamwe. ${ }^{11}$ The idea that female promotion must also include women's empowerment through access to the public sphere and to political power was first raised by a lively civil society, rapidly struck down by war and the genocide against the Tutsi. After 1994, all these associations restarted their activities and many new groups were created. They

\footnotetext{
${ }^{10}$ Pauline Nyiramasuhuko was the first woman to be convicted by the International Criminal Tribunal for Rwanda: she was found guilty of genocide and incitement of rape.

${ }^{11}$ Profemmes Twese Hamwe means 'women together'.
} 
made an amazing contribution to the reconstruction and development of Rwanda and the reconciliation process. Among them, and perhaps the best-known at an international level is Avega, an NGO founded by 50 genocide survivors - widows, created to address the needs of genocide widows, orphans, children heads of households, those who lost their children, older people and people with disabilities.

More relevant is the fact that women's empowerment in Rwanda today is not entrusted to civil society only, but it has become an important government program. As President Kagame has said: ‘Gender equality is not just women’s business, it is everybody’s business; gender equality and women's empowerment are critical to sustainable socio-economic development' (Ministry of Gender and Family Promotion 2010, pp. 10-11). To promote women became a necessary strategy for reconciliation, reconstruction and development, in order to involve the whole population in this challenging task.

Women therefore came to be conceived not only in the private and domestic sphere, but also in the public one. Their entrance (or their return) to politics and power certainly represented a substantial change in the history of women's empowerment, allowing them to finally come out from a colonial ideology of female promotion which had left its mark on their lives for too long.

\section{Women's Empowerment Today}

Gender equality and women's empowerment have become a national priority. Rwanda has adopted some important policies and programs which clearly show this commitment: the Rwandan Constitution of 2003, which instituted affirmative action; Vision 2020, which stated that gender has to be integrated as a cross-cutting issue in all development policies and strategies; the Economic Development and Poverty Reduction Strategy 2008-2012 (EDPRS), which analyzed the still existing gender inequalities, including within the education sector; and the National Gender Policy, which was revised in 2010. Important institutions were created in order to implement these policies, such as the Ministry of Gender and Family Promotion (MIGEPROF), National Women's Council and Gender Monitoring Office. Lastly, Rwanda is the country with the highest percentage of women parliamentarians in the world (56\% since 2008). 
Despite all these important achievements, which show a dramatic change in politics and public discourse, more has still to be done to completely overcome gender imbalances at all levels of society. An example is the education sector.

The main purpose of education today in Rwanda is to prepare all young people, both boys and girls, to be active and competent participants in society as a whole and to be productive economic contributors to the workforce. Moreover, Rwanda is committed to building a 'knowledge-based, technological' society, which means that the development of educational Institutions is a priority too.

Rwanda has adopted the 2008 Education Sector Strategic Plan, the Joint Education Sector Support 2006-2010, the 2008 Girls’ Education Policy revised in 2010, and the 2009 Girls Education Implementation Strategy. All these documents put gender equality in education as their central objective. However, a persistent gender imbalance emerges when reading analyses of retention, transition and completion rates in secondary and tertiary education in Rwanda. ${ }^{12}$ Gender equality has been reached in primary school: 51 percent of the enrolled children are girls, girls' transition rate is 86.3 percent (while boys' is $89.9 \%$ ) and girls' examination pass rate is 50.8 percent (while boys' is $49.2 \%$ ). Regarding teachers, 51.8 percent of the faculty are women, and 96.3 percent of them are qualified. The situation in secondary education is different. The enrollment rate is almost equal (49\% are girls and 51\% are boys) as well as the transition rate ( $86.9 \%$ for girls and $85.2 \%$ for boys). However, the examination pass rate reveals a large imbalance: only 44 percent of girls succeed in the final exams compared with more than 55 percent of boys. Only 21.8 percent of the faculty is represented by women and only 20.2 percent of them are qualified. Girls' disadvantaged position is more evident at the tertiary level, where only 43 percent of the students enrolled are girls (including in private universities) and only 21 percent of the faculty in the public universities is represented by women. At the National University of Rwanda (NUR), out of $126 \mathrm{PhD}$ holders, only 14 are women (Masanja et al. 2011, p. 20).

Even the access to government university scholarships reveals inequalities: at NUR, Kigali Institute of Science and Technology (KIST) and Kigali Institute of Education (KIE) the percentage of female recipients of scholarships is under 30 (23.3\% at NUR, $21.2 \%$ at KIST

12 Randell and Fish (2011), p. 8. Statistics in this and the next paragraph are drawn from this publication. 
and 26.6\% at KIE), whereas at the Higher Institute of Agriculture and Animal Husbandry (ISAE) the percentage is 35, and at Kigali Health Institute (KHI) the percentage is 50.3. This shows that some old gender patterns die hard: the highest percentage of women in tertiary education is found at KHI, where health workers (nurses, anesthetists) are trained, while the lowest one is found at KIST, the university for science and technology education.

The participation of women in science and technology fields is still weak at both secondary and tertiary education levels. Only 19 percent of women studied agriculture in 2005 while those studying science and technology stood at 16 percent at NUR in 2005. In 2008, the overall enrolment had declined to 13.9 percent (Kwizara 2010, p. 2). An aborted Girls' Empowerment Program in 2006, which led to 90 girls enrolling in science and technology courses in 2007 and increased female enrolments to 20 percent, was discontinued. The Ministry of Education has resurrected the Girls Empowerment Program in 2010 by selecting 100 young science students who narrowly missed government sponsorship in 2008 and 2009 to join higher institutions of learning pursuing science and technology courses under the Equal Opportunity Program. The African Development Bank is funding this program that targets the enrolment of an additional 200 girls in tertiary institutions by the end of 2011. One program goal is to improve science and technology and Rwanda's industrial skills base by building the capacity of female students.

\section{Conclusion}

As we have seen in this brief reconstruction of the history of women's empowerment in Rwanda, colonization brought profound changes to the position of women in the nation. The political status of the pre-colonial élite of powerful women transcended their gender status. However, the dismantling of the monarchy with its roles and symbols, among which was the figure of the queen mother, led to women's retirement from political power. The colonial powers introduced strong sex and class inequalities and strict gender ideologies. Memorable among the structures that eroded women's power were the foyers sociaux, an educational welfare program which supported female promotion for an élite group of women in urban areas with the objective of making them suitable partners for the chosen évolués and under male control. This completely reversed the gender power relations existing in rural areas where women were important agricultural workers. In the new replicated urban nuclear families, men were seen as the producers and women as the re-producers needing social control. Far from being emancipated, women became domesticated in their roles, which 
mimicked the roles of expatriate wives and mothers. The establishment of the Karubanda Social School for girls continued this pattern, training indigenous assistants who could work in the foyers sociaux.

Women themselves began to change this situation following the international influence on Rwandan participants of the 1985 End of the Decade Conference for Women held in Nairobi, when they began their own empowering organizations. These were devastated in the 1994 genocide against the Tutsi, but were re-established by determined women to become powerful instruments of reconciliation, reconstruction and development. Education stands out as one of the most important sectors that must be reformed in order to empower women and reach gender equality at all levels of society. Not only must equality in education be conceived in terms of percentages of people enrolled at universities and graduates with degrees, but it must also coincide with access for women to all fields of education and employment, especially in the fields of science and technology, on which Rwanda is now basing its development.

\section{Acronyms}

AVEGA Association des Veuves du Genocide d'Avril (Association of Genocide Widows)

CCDFP Centres Communaux de Développement et Formation Permanente

CGCD Centre for Gender, Culture and Development

GMO Gender Monitoring Office

ISAE Higher Institute of Agriculture and Animal Husbandry

KHI Kigali Health Institute

KIE Kigali Institute of Education

KIST Kigali Institute of Science and Technology

MIGEPROF Ministry of Gender and Family Promotion

MINEDUC Ministry of Education

NUR National University of Rwanda

NWC National Women Council

UN United Nations

\section{References}

Agamben, G. 2009, What is an apparatus? and other essays, Stanford University Press, Stanford.

Amadiume, I. 1987, Male Daughters, Female Husbands. Gender and Sex in an African Society, Zed Books, London. 
Cohen, R. 1977, 'Oedipus Rex and Regina: The Queen Mother in Africa', Africa: Journal of the International African Institute, vol. XLVII no.. 1, pp 14-30.

Congrès Colonial National, 1956, XII Session: la promotion de la femme au Congo et au Ruanda Urundi. Rapports et compte rendu, Bruxelles.

De Heusch, L. 1958, Essais sur le Symbolisme et l'Inceste Royal en Afrique, Université Libre de Bruxelles, Institut de Sociologie Solvay, Etudes Ethnologiques, Bruxelles

De Heusch, L. 1962, Le Pouvoir et le Sacré. Annales du Centre d'Etude des Religions. Université Libre de Bruxelles, Bruxelles.

De Heusch, L. 1972, Le Roi Ivre: ou l'Origine de l'Etat, Gallimard, Paris.

Fusaschi, M. 2000, Hutu-tutsi. Alle radici del genocidio rwandese, Bollati Boringhieri, Torino.

Government of Rwanda, 2003, Rwandan Constitution, Republic of Rwanda, Kigali.

Guichaoua, A. 2005, Rwanda 1994: les politiques du génocide à Butare, Karthala, Paris.

Hunt, N. R. 1990, 'Domesticity and colonialism in Belgian Africa: Usumbura's foyer social, 1946-1960’, Signs, vol. XV, no. 3, pp. 447-474.

Kwizara, C. 2010, The New Times, 21-12-2010, p. 2.

Masanja, V., De Silva, N., Uwizeye, D. \& Niragire, F. 2011, Empowering Women in Research: The Case of the National University of Rwanda, Nostra, Stockholm.

Meillassoux, C. 1975, Femmes, greniers et capitaux, François Maspéro, Paris.

Ministre des Colonies, 1952, Rapport sur l'administration belge du Ruanda-Urundi pendant l'année 1951, Etablissements généraux d'imprimerie, Bruxelles.

Muzungu, B. 2003, L'histoire du Rwanda pré-colonial, l’Harmattan, Paris.

Ngendakumana, M. 1989, L'école sociale de Karubanda et l'intégration de la femme rwandaise au développement, Typescript.

Prunier, G. 1995, The Rwandan crisis: history of a genocide, C. Hurst \& Co, London.

Randell, S. \& Fish, J. 2011, 'Gender gaps remain in the education of girls in Rwanda and increase at the tertiary level', Centre for Gender, Culture and Development Occasional Research Paper, 6.

Republic of Rwanda, 2003, Vision 2020, Republic of Rwanda, Kigali.

Republic of Rwanda, 2007, Economic Development and Poverty Reduction Strategy 20082012 (EDPRS), Republic of Rwanda, Kigali.

Republic of Rwanda 2008, National Constitution. Kigali: Republic of Rwanda.

Republic of Rwanda, MINEDUC, 2006, Joint Education Sector Support 2006-2010, Republic of Rwanda, Kigali.

Republic of Rwanda, MINEDUC, 2008, Education Sector Strategic Plan, Republic of Rwanda, Kigali.

Republic of Rwanda, MINEDUC, 2008, Girls’ Education Policy, Republic of Rwanda, Kigali.

Republic of Rwanda, MINEDUC, 2008, Indicators for Primary, Secondary and Tertiary Performance. Organizational documents, Republic of Rwanda, Kigali.

Republic of Rwanda, MINEDUC, 2008, Joint Review of the Education Sector, Aide Mémoire, Republic of Rwanda, Kigali.

Republic of Rwanda, MINEDUC, 2010, Girls Education Implementation Strategy, Republic of Rwanda, Kigali. 
Republic of Rwanda, Ministry of Finance and Economic Planning, 2000, Rwanda Vision 2020, Republic of Rwanda, Kigali.

Schiller, L. D. 1990, 'The royal women of Buganda', The International Journal of African Historical Studies, vol. XXIII no. 3, pp. 455-473.

Vansina, J. 2004, Antecedents to Modern Rwanda: the Nyiginya Kingdom, University of Wisconsin Press, Madison. 